\title{
THE INTEGRATIVE MANAGEMENT MODEL FOR RESTRUCTURING SMALL AND MEDIUM-SIZED ENTERPRISES (SME)
}

\author{
Andrius Tamošiūnas
}

\section{Introduction}

Restructuring processes are continuous in market economies. Technological progress, diffusion of innovations results in market disruptions and convergences. The latter create new markets and value networks, impact the scope and scale of consumption and related businesses changing the nature of competition and market dynamics. Such evolution affects all sectors of economic systems including processes of integration and globalization, causing enterprises to restructure in order to maintain or strengthen their market position. The last decades of the global economy (including the latest economic crisis) showed restructuring as a radical and complicated way of reconstruction related to a great risk due to its essentiality and extent; thus, it is vital both for SMEs and economic systems. Yet by the definition (EC, 2005), data on SMEs is fragmented, limited and publicly unavailable. Consequently, scientific researches on SME restructuring are scarce and fragmentary. There has been no research to form the basis for preparation and effective implementation of economically justified SME restructuring programmes (plans) made until now. Having in mind the context, the paper synthesizes a vast spectrum of literature and empirical data in the attempt to systematically approach this issue with specific focus on rationalization of SME restructuring processes as a complex. For this purpose, the author proposes the integrative model for the management of SME restructuring programmes that allows rationalizing the management of restructuring process and the use of human, material and financial resources. This enables SMEs to identify, adjust and implement measures for reconciliation of controversial management methods in order to strengthen and balance interactions between strategic, tactical and operational tasks. In addition, this helps to focus on permanent improvement of management systems of SMEs seeking for divergent and sustained competitive performance.

\section{SME Restructuring in EU}

Restructuring is a prerequisite of economic systems whereas business entities must adapt to dynamic target environment and shape it in order to remain resilient and competitive. The majority of studies, however, cover issues of larger restructuring cases and focus less of SMEs, which represent more than $99 \%$ of European businesses and contribute to nearly $50 \%$ of global GDP (EC, 2005).

As per findings stemming from the analysis of SME restructuring cases in the EU during the last 10 years, SME restructuring is often reactive and unplanned. Yet once started, decisions are quick and flexible. As leaders, owners and CEOs (reporting directly to owners) are keen to improve in terms of time, effort and money. Grounds for such insight have also been found when interviewing 18 Lithuanian, 26 Latvian enterprises during the period of 2008-2013 seeking to examine why and how businesses have been influenced by restructuring. It was observed that SME restructuring often represents one of the following types:

- internal restructuring (adjustment of internal processes or structures and their interaction) - heterogeneous and due for business expansion or bankruptcy, closure or outsourcing via sub-contracting (e.g., accounting, legal services, maintenance of $\mathrm{IT}$, transportation) locally and internationally (e.g., consultancy); yet also caused by relocation and merger/acquisition. While this type is the most informal (limiting the amount of official statistical data), it prevailed during 2005-2010 in Europe (EC, 2013a; EIM, 2010; De Kok et al., 2011) taking the following forms: 
$\square$ change strategies, incl. diversification, expansion, and cost cutting prevailing during the peak of recession in 2009;

$\square$ upgrade of internal processes and structures;

production upgrade;

communication networks upgrade;

business transfers and successions and this trend is anticipated to continue up to 2021 (EC, 2006; Kowalewska, 2010).

Although cost cutting is the most prevalent form of internal restructuring (Gallup, 2007; Orlowski et al., 2010; 4Results, 2009; OECD, 2013) and includes outsourcing (accounting, IT, legal and back office services and other more standardized functions such as transportation), innovation of products, processes and management structures can also be applicable;

- relocation - as the choice of business area depends on the place of residence of the owner and the strength of ties to the local personal and business networks, relocation has little importance for SMEs. Other possible constrains are related to property costs/rent, wages, markets or available workforce, e.g.: i) in Lithuania, the level of SME relocation is higher in the service sector than in the production sector as equipment is rather mobile and premises are standard; ii) in the UK, high-technology firms are less mobile due to reliance on their regional, social and business networks, including workforce (Galbraith et al., 2008);

- outsourcing - while common to larger entities that subcontract SMEs for specific tasks, it is actually becoming more relevant to SMEs acting as contractors (e.g. in construction, transport and communication, IT and business services): $20 \%$ of SMEs in the EU are outsourcing (Grüne, 2009; EIM, Ikei Research and Consultancy, 2009);

- closure and (or) bankruptcy - according to data on enterprises in Europe, the recession resulted in the greatest number of SME bankruptcies (80-90\% during 2007-2011 with $99 \%$ for Lithuania during 2001-2011) (Eurostat, 2011; 2013);

- merger or acquisition (M\&A) - as EU average figure of $M \& A s$ in the $E U$ is 3 times higher for larger entities, SMEs are mainly targets rather than initiators of M\&A. The following dominant drivers for M\&As with SMEs can be found: concentration (for France, Lithuania and Spain); tackling impacts of recent crisis or expanding via buying entities in crisis (for Belgium, Denmark, France, Poland and the UK);

- offshoring and (or) delocalization was particular to the average of $\sim 10 \%$ of SMEs during 2004-2011 in the EU (CSO, 2008; Deschryvere \& Kotiranta, 2008; EIM, 2010; IME GSEVEE, 2012) with fluctuations caused by the latest crisis.

As for SME restructuring causes, external reasons are similar to those of larger corporate restructuring cases, while internal reasons are specific, namely:

- limited resources in scale and scope (e.g. to outsource and engage in other efficiencyimproving actions);

- change of ownership - this brings new business and management approaches (this is also inherent to larger cases);

- owner's ambitions (e.g., to expand or shrink, redirect or diversify);

- reliance on few partners and clients - this may cause changes driven by requirements of the latter.

SME restructuring is caused by a combination of both internal and external factors with the greater impact of the former, e.g. (EC, 2007; Voss, 2009; Wymenga et al., 2012):

- relocation is caused by specifics of owner's personality, macroeconomics and public regulation;

- bankruptcy and (or) closure is due to internal constraints, macroeconomics and dependency on partners.

For instance, in terms of public regulation, the following aspects should be considered:

- State policies on foreign direct investment result both in subcontracting opportunities, which may cause internal restructuring aimed at relevant internal upgrades and in consolidation patterns causing M\&A via SMEs.

- State policies promoting high-growth and export-oriented sectors cause SMEs to restructure (change their profile) in order to benefit from such policies, e.g. utilization of EU Structural Funds and other similar instruments (EC, 2013b).

- Taxation system (e.g., growing wages, taxes and emergence of new taxes), less transparent public procurement and administrative barriers (e.g. stricter requirements on renewable energy 
solutions, shale gas exploration, nuclear power plant construction, energy market liberalization activities etc.) endanger SMEs (by causing bankruptcy and (or) closure) and push them to search for new strategies: internal restructuring may be employed as a solution in case of the lack of working capital and lower taxes and business costs may lead to SMEs offshoring and (or) delocalisation and their further internationalization (KPMG, 2007; 2009; Kitching et al., 2010; 2011; Kowalska, 2015).

- Infrastructure decisions, e.g., (re)building highways \& railways, public and private building renovation or the expropriation of land for business may cause SME relocation.

As for macroeconomics, fluctuations in consumption habits, exchange rates, commodity prices and inflation may lead to internal restructuring (Orłowski et al., 2010; Eurostat, 2013; Tamošiūnas, 2014) or even cause a bankruptcy/closure in case of failure. The causes for internal restructuring - sudden lack of demand, limited working capital and access to external financing - co-relate with dismissals, reduced costs and working hours through outsourcing (BSMEPA, 2011; OECD, 2013). Under such circumstances, new business opportunities will also arise from internal restructuring, diversification and M\&A targeting businesses in distress. In this respect, any potential for demand (or its growth) may render the internal systems inadequate and lead to internal restructuring as well. Hereby globalization stimulates outsourcing and competition locally and internationally, reshaping core competences of SMEs, products and value networks, which results in internal restructuring (delocalization and diversification is possible as well (Eurostat, 2013; OECD, 2013). In this respect "long tails" (Anderson, 2008) of widespread technological progress provide SMEs with niche business opportunities causing greater heterogeneity that results in internal restructuring and outsourcing. Of course, demographic change and emigration cycles also reshape core competences, products and value networks of SMEs, leading to internal restructuring or outsourcing and transfer of ownership via M\&A, although it can be limited to reorganization alone (Cope, 2011; Kontinen, 2011; Dervillé \& Allaire, 2014).
In this context, with unlimited power as direct liability and driven by own interests, the owner or manager of an SME may use any of restructuring solutions mentioned above (Mandl, 2008; Tamošiūnas, 2014; Ruiz \& Coduras, 2015), e.g. limited financial and human resources as well as the need to reduce production costs may result in outsourcing or merger, relocation or delocalization or offshoring. In this respect SMEs are also more flexible in avoiding or recalling value-destroying restructuring (Aidis \& Van Praag, 2007; Sauka \& Welter, 2013) even with higher risk of poor management as SME management teams are small or limited to a manager or owner. In addition, the observed SMEs dependency on one or a few key clients or suppliers might require internal restructuring or business expansion to comply with business specifics (e.g. standardization or differentiation of products, processes, resources, diversification of markets, etc.) of the partner company. The risk of dependency on one or a few sources might result in bankruptcy or closure, or at least in an internal restructuring to adjust to the demand shifts, e.g.: postponed public investments and delayed payments as demonstrated by facts from UK, the Baltic States, France, Romania, Slovenia, Slovakia (Kelly et al., 2011; De Kok et al., 2011; Bosma \& Amoros, 2013; OECD, 2013). For example, if SMEs act as subcontractors, partner relocation might also cause SMEs to relocate or otherwise adjust due to transportation costs.

Such a wide and dynamic context in scope and scale of factors specified above reveals the necessity for complex improvement of management of SME restructuring. SMEs need solutions that would enable them to act in the dynamic economic environment, to rationalise the management of the combination of its human, material and financial resources and other relevant assets, thus increasing competitiveness in a sustained and effective manner.

\section{The Integrative Management Model for SME Restructuring}

Having in mind the context of para 1 it can be stated that restructuring is subject to strategic management techniques used to rationalise the activity of an enterprise and resulting in essential changes of the corporate strategy and structure in pursuit of improvement of competitiveness in 
a clearly defined time outlook taking a multitude of proactive (e.g. planned redirection or growth) and reactive (e.g. avoiding "black swans") forms. When restructuring an enterprise, it is typical to apply a set of wide spectrum measures and methods for strategic and tactical tasks as well as reach at least a few objectives. In this respect, the analysis of data gathered and processed, including empirical investigations and considering research results of various scientific investigations on SME restructuring cases (including those mentioned in para. 1), allow defining the integrative management model for SME restructuring (Fig. 1) more precisely.

\section{Fig. 1: The integrative management model for SME restructuring}

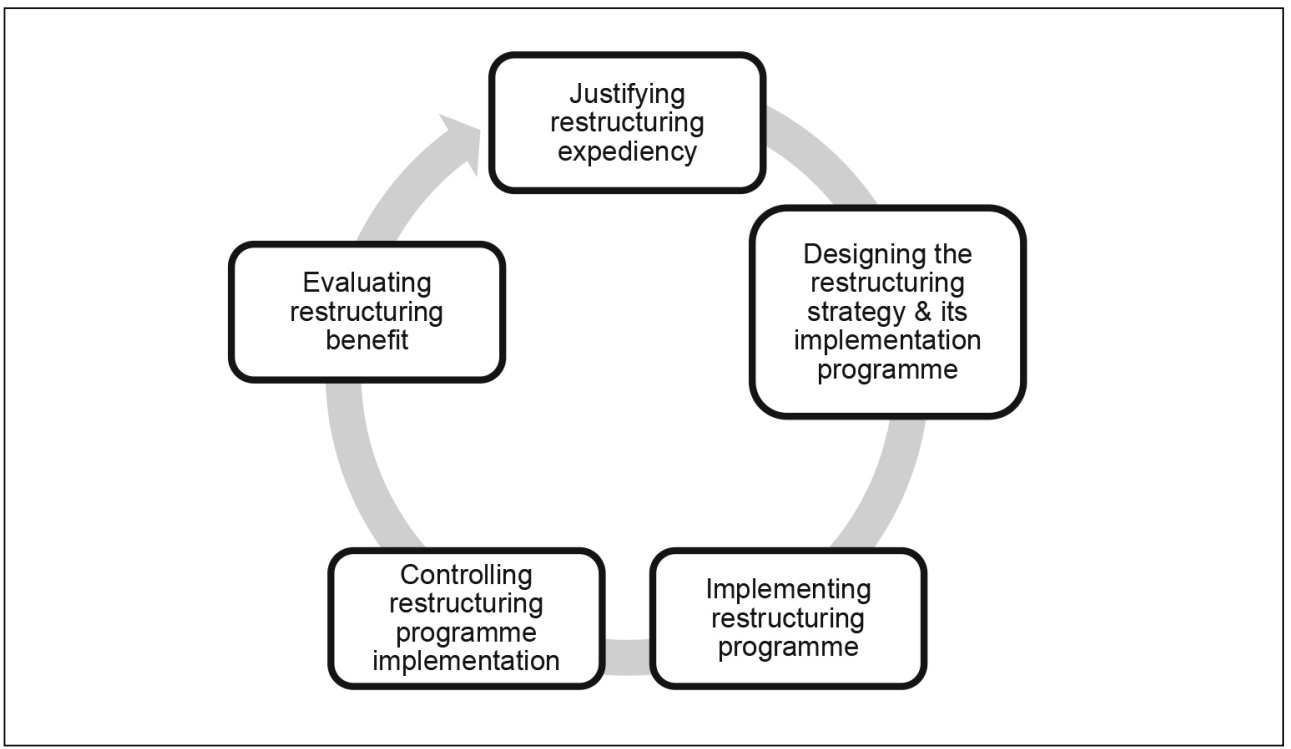

The model consists of the following phases composing the integral cycle of SME restructuring process: 1) justifying the restructuring expediency; 2) designing the restructuring strategy and its implementation programme; 3 ) implementing restructuring programme; 4) controlling restructuring programme implementation; 5) evaluating restructuring benefit. Each phase is specified in the following paragraphs.

\section{Justifying the Expediency of SME Restructuring}

First of all, in order to justify the expediency of SME restructuring, it is necessary to evaluate the current efficiency of SME activity, identifying strengths, weaknesses and possible threats for its competitiveness in the context of the current strategy and viability of its use. To solve this task, a wide spectrum of indicators of economic and financial analysis is often applied in practice including such techniques as SWOT, SPACE, various modifications of Balanced Scorecard and Boston Consulting Group Matrix. Many qualitative indices are used in relation to these methods. These indices are evaluated in conditional quantitative gauges (scores) that are subjective. In order to increase objectivity while evaluating enterprise efficiency, it is necessary to apply some of the above-mentioned methods (or their combination) and justify conclusions by synthesis of results received applying distinct methods. Aiming to make rational use of 


\section{Fig. 2: Scheme for justifying the expediency of SME restructuring}

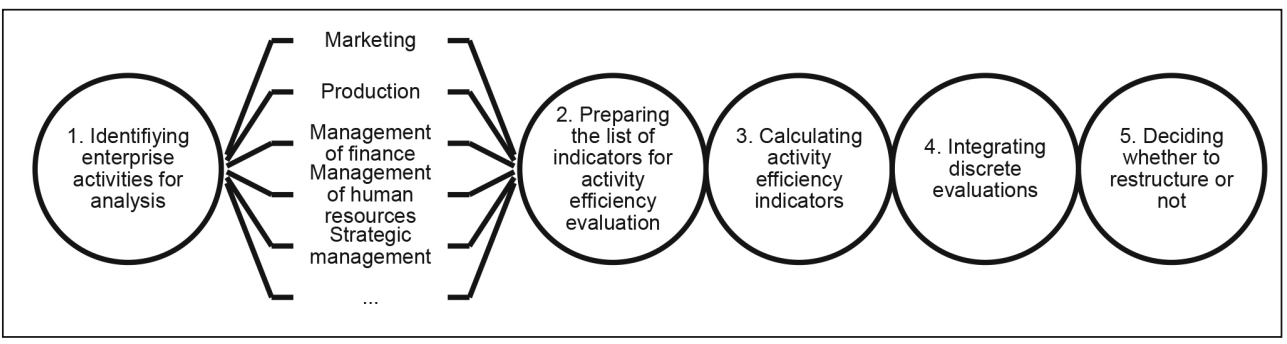

Source: own

possible merits of evaluation methods in cases of SME restructuring, it is proposed (when evaluating efficiency of enterprise activity) to apply the combination of techniques mentioned above in the order provided in Fig. 2.

It is proposed to divide the enterprise efficiency evaluation object into two parts: strategic management and functional management. The interaction between the strategic analysis, the use of resources, the strategic control and organisational management structure is evaluated in the strategic management part. Efficiency of marketing, finance, human resources and technologies/production is subject to functional management evaluation. The list of functional management activities may vary depending on SME business specifics.

The following qualitative criteria are proposed to evaluate the efficiency of strategic management (evaluation is made using scores, applying ten-point evaluation system): a) the ability to foresee new possibilities for the activity and the possible negative affect of the changes of external factors to the results of enterprise activity as well as to avoid or reduce that affect; $b$ ) the efficiency of the use of human, material and financial resources; c) the validity of management decisions; d) the efficiency of enterprise management system.

The following criteria are proposed to evaluate functional management:

1. for marketing efficiency (quantitative): a) the ratio of enterprise product sales to product sales of entire market; b) the ratio of enterprise product quality level to the main competitor (s) product quality level (scores are used for evaluation); c) the ratio of enterprise product price to the main competitor (s) product price; d) the variations of the indicators of $a, b, c$ per last 5 years of enterprise activity;

2. for production efficiency (quantitative): a) the ratio of produced volume of enterprise product to its production costs; b) the ratio of product price to the production costs; c) the ratios of product volume produced to the volume of material resources used for production (by the type of the resources used for production in physical terms); d) the ratio of time-span of operations execution to the number of the personnel executing these operations; e) the variations of indicators of $a, b, c$ and d per last 5 years of enterprise activity; $f)$ the ratios of indicators of $a, b, c, d$ and $e$ to respective indices of main competitor (s) (it is evaluated under e criteria, given that the enterprise has enough data about the activity of competitors);

3. for the efficiency of management of finance (quantitative): a) profitability; b) liquidity; c) payback of investments; d) return on equity; e) asset turnover; f) the ratio of enterprise share market value to enterprise share nominal value; $g$ ) the variations of indices of a, b, c, d, e and f per last 5 years of enterprise activity; $h$ ) the ratios of indices of $a, b, c, d, e, f$ and $g$ to respective indices of the main competitor (s) (it is evaluated under $\mathrm{h}$ criteria, given that enterprise has enough data about activity of competitors);

4. for the efficiency of human resource management (quantitative): a) career possibilities; b) compatibility of employees and their functions; c) possibilities to 
increase qualification level; d) the quality of team work and its stimulation possibilities; e) acknowledgement and evaluation of achievements; f) stimulation of activity (authority provision); g) employees' participation in decision making; $h$ ) employees social security and care.
Having evaluated the activity efficiency following the above-mentioned criteria, results are distributed in the grid (Fig. 3) by crossing points determined with respect to the level of efficiency (i.e. low, middle or high) and the level of efficiency dynamics (i.e. low, middle or high) of functional management.

\section{Fig. 3: Evaluating SME management efficiency}

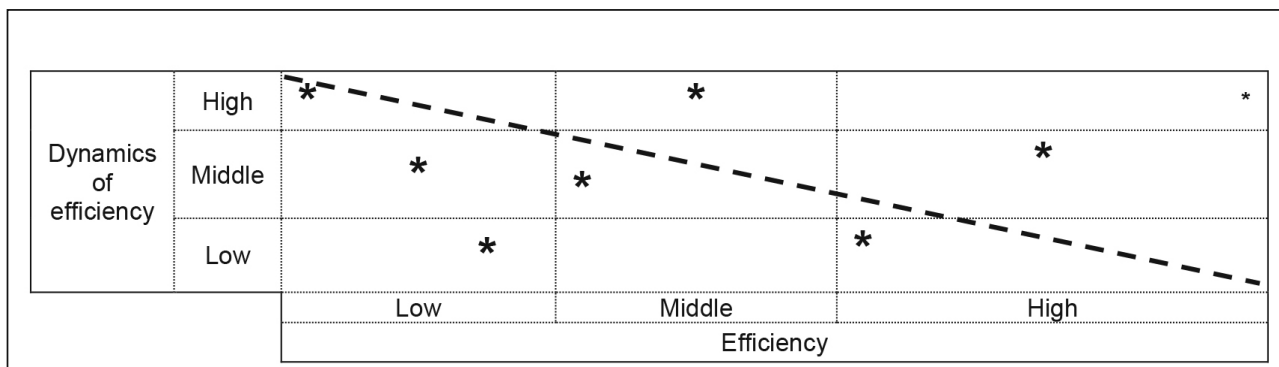

Source: own

When determining the level of efficiency dynamics, at least a 3-year business period is recommended for analysis. A longer business period is welcomed; however, it has to be reasonable as it causes additional expenditure related to deployment of necessary human, material and financial resources.

If at least two components of SME functional management score efficiency results situated below the dashed line (Fig. 3) that represents the efficiency benchmark (which is set based on comparable efficiency indicators of main competitor(s) (various other micro and macro comparable indicators can be chosen depending on case specifics) of the SME in question), it is recommended to restructure the SME.

\section{Designing the Restructuring Strategy and Its Implementation Programme}

Any enterprise restructuring strategy is unique. Firstly, it is one of the main requirements for each efficient strategy. Secondly, it is determined by a variety of external political, economic, social and technological factors that create prerequisites for choosing the relevant set from the available plenitude considering the restructuring case. In this context having identified the expediency for SME's restructuring as per para. 3 , it is proposed to prepare respective strategy and its implementation programme according to the order set in Fig. 4.

When making SME restructuring decisions, it is necessary to assess restructuring reasons as well as goals relying on conclusions of enterprise activity efficiency evaluation. The executed analysis allows determining regularities of SME restructuring decisions (Tab. 1).

When preparing the strategy and seeking for the best strategic decisions, it is necessary to analyse the possible results of alternatives of the considered strategy applying the technique of comparative analysis as well as techniques optimizing the decision making.

As SME restructuring is subject to strategic management techniques, it is based on the programme (or plan) of objectives and their tasks aimed at changing SME activities, covering the complex of related measures and ways, which content-wise are similar to the programme for the implementation of the corporate strategy at tactical and strategic levels of enterprise management. 


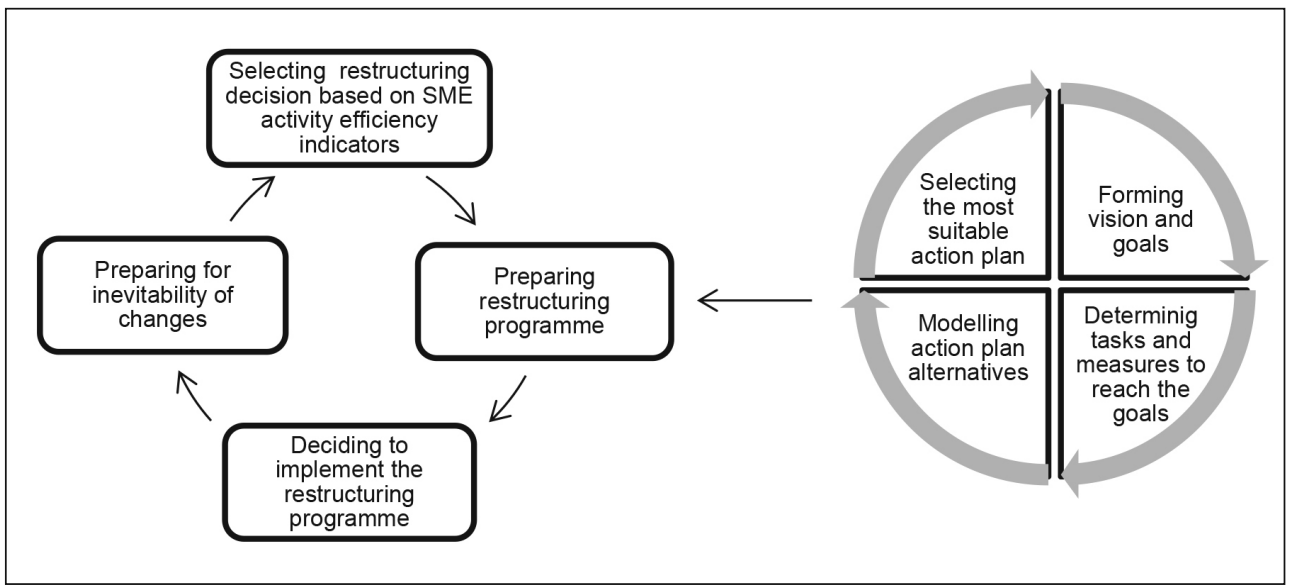

Source: own

\begin{tabular}{|c|c|c|c|c|}
\hline \multirow[b]{2}{*}{ SME business strategy } & \multicolumn{4}{|c|}{ SME restructuring strategy } \\
\hline & $\begin{array}{l}\text { Horizontal } \\
\text { integration }\end{array}$ & $\begin{array}{c}\text { Vertical } \\
\text { integration }\end{array}$ & Concentration & Conglomeration \\
\hline Product & $x$ & $x$ & & \\
\hline Business family & & $x$ & $\mathrm{X}$ & \\
\hline Portfolio & & & & $x$ \\
\hline
\end{tabular}

In the context of research results, the following aspects are considered the main with respect to the content of SME restructuring programme (Tamošiūnas, 2014):

- enterprise activity objectives (long and short-term);

- alternatives of restructuring decisions, restructuring techniques, validity of their application;

- the demand for human, material and financial resources and other assets necessary for their application;

- the possible benefit of the strategy to the enterprise (if implemented) and risk factors that may reduce this benefit;

- changes in the organisational management structures required in order to implement the strategy;
- necessary changes in human resources (staff reduction, recruitment, change in functions, authority and responsibility);

- changes in functional strategies (concentrating on departments and divisions with the lowest efficiency level);

- forecast of restructured SME activity results and their comparison with expected results of competitor activity;

- restructuring strategy implementation plan, indicating tasks to be solved and persons as well as divisions responsible for execution of tasks (including time schedules).

As for determined regularities (Tab. 2), selection of the restructuring technique depends on SME restructuring goals. Their application is recommended during the design of the programme. 


\section{Tab. 2: Matrix for selection of restructuring strategy implementation techniques}

\begin{tabular}{|c|c|c|c|c|c|c|c|c|c|c|c|c|}
\hline \multirow{2}{*}{\multicolumn{2}{|c|}{ Restructuring purposes }} & \multicolumn{11}{|c|}{ Restructuring techniques } \\
\hline & & 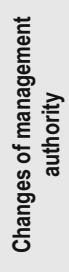 & 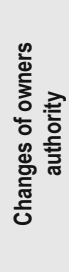 & 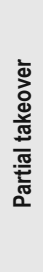 & 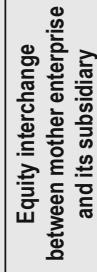 & 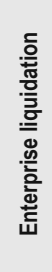 & 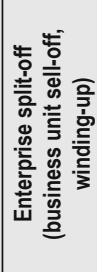 & 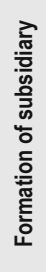 & 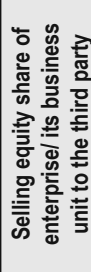 & 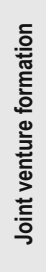 & 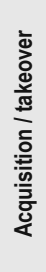 & 㷰 \\
\hline \multicolumn{2}{|c|}{$\begin{array}{l}\text { Business expansion and/or } \\
\text { developments }\end{array}$} & & & & & & & & & $x$ & $x$ & $x$ \\
\hline \multicolumn{2}{|c|}{ Maintaining market share } & & & & & & & & & & $x$ & $x$ \\
\hline \multicolumn{2}{|l|}{ Overcapacity } & & & & $x$ & $x$ & $x$ & $x$ & $x$ & & & $x$ \\
\hline \multicolumn{2}{|c|}{ Portfolio management } & & & & $x$ & $x$ & $x$ & $x$ & $x$ & & & \\
\hline \multicolumn{2}{|c|}{ Rationalizing management } & $x$ & $x$ & $x$ & & & & & & & & \\
\hline \multirow{2}{*}{$\begin{array}{l}\text { Restructuring } \\
\text { type }\end{array}$} & External & & $x$ & $x$ & $x$ & $x$ & $x$ & $x$ & $x$ & $x$ & $x$ & $x$ \\
\hline & Internal & $x$ & $x$ & $x$ & $x$ & $x$ & $x$ & & & & & \\
\hline
\end{tabular}

Source: own

The restructuring type (Tab. 2) is selected depending on the significance of disadvantages and advantages of the enterprise, which are identified during the evaluation of enterprise activity efficiency.

Making the decision regarding the implementation of the programme, it is proposed to evaluate the restructuring programme using the following criteria (Tamošiūnas, 2014): 1) financial capacity; 2) enterprise business development potential; 3) product competitiveness; 4) productivity of technologies and production; 5) labour productivity; and 6) market share.

Having made the decision to restructure the $\mathrm{SME}$, it is necessary to prepare the enterprise for inevitability of changes. In this respect, proper combination of strategic priorities of enterprise activity as well as the support of relevant (the theory of tipping points (Gladwell, 2000) functional managers and employees will contribute to the success of SME restructuring.

One of the first tasks of restructuring programme implementation is to renew strategic management system. The second task is to rationalize enterprise management in terms of efficiency increase of its business strategy and its functional strategies. Next follows the execution of the programme tasks at the level of enterprise functional departments and business units.

\section{Improving the Strategic Management}

The purpose of the task aiming improve the strategic management system is to rationalize the execution of main strategic management functions of an SME (corporate management, production, finance, marketing, innovation and human resources management) at operational, tactical and strategic levels. In order to solve this task, it is necessary to select the set of measures and techniques allowing to form the combination of human, material and financial resources, the efficiency of which at operational, tactical and strategic levels would exceed the efficiency level of strategic management of a non-restructured SME. In this context, the efficiency of strategic management $(E)$ could be formally expressed in the following manner:

$$
E=f\left(E_{h}, E_{m}, E_{f}\right),
$$

where $E_{h}$ - the efficiency of the use of human resources; $E_{m}$ - the efficiency of the use of 
material resources and other property; $E_{f}$ - the efficiency of the use of financial resources.

In terms of SME strategic management, efficiency measures and techniques for creation of possibilities to increase the efficiency of use of enterprise resources as well as their application procedures have to be provided within restructuring programme, i.e.:

$$
\begin{aligned}
& E_{h}=f(R, J, A) \geq E^{0}, \\
& E_{m}=f(R, T, A) \geq E^{0}, \\
& E_{f}=f\left(R, C_{M}, A\right) \geq E_{f}^{0},
\end{aligned}
$$

where $R$ - sales in monetary terms, $J$ - number of employees; $T$ - value of the active share of assets (production measures); $A$ - indicator of asset turnover; $C_{M}-$ cost of materials. The following are respective indicators of a nonrestructured enterprise: $E_{h}^{0}, E_{m}^{0}, E_{f}^{0}$

With regard to SME strategic management efficiency, it is recommended to develop the following:

a) the possibilities for multifunctional application of resources;

b) the technological and production resources

creating the competitive advantage.

In terms of security of resources creating the competitive advantage, the level of concentration of enterprise management rights, endowing the authority to control and manage the enterprise, would provide the greater possibilities to control these resources and minimize the risk of their loss.

The possibilities of multifunctional application of enterprise resources with regard to production mass customization and "long tail" (Anderson, 2008) opportunities form conditions for expedient change of enterprise strategy and its implementation techniques, thus contributing to SME competitiveness in the markets, both dynamic and heterogeneous. This is especially important trying to maintain or increase the SME market share in the markets as receptive to innovations as well as subject to the products of relatively short life cycles (e.g. in the markets of information technologies, internet service, wireless communication, biotechnologies and, in certain cases, food industry) as energy intensive (e.g. sectors of heat and power, cement and quicklime, coke and steel, fertilizers and other chemicals, construction and wood processing materials, and paper production).

The application results of this technique for improvement of the strategic management system, when implementing the SME restructuring programme of a construction materials producer, show that the SME is in disposition of measures that create the possibility to reach the level of strategic management efficiency which exceeds the one the enterprise has had before restructuring (Fig. 5).

As in case of the above-considered example as for the purpose to justify the utility of practical application of other techniques proposed in this paper the one of major Lithuanian construction materials producer was chosen. The author had a privilege to consult the enterprise in question on business development issues (and test the model presented in this paper) since 2006. In connection to this the following conditions have also been applied respectively:

- the restructuring period of two years was selected due to the following reasons: a) the specifics of the SME, b) results of findings as per para. 1 and various analysed scientific and other data sources, which stress the importance of a relatively rapid restructuring as to ensure better results;

- the seven-year forecasting period was chosen due to the following factors: a) specifics of activity and strategic plans of SME in question cover the period from five to seven years, b) an average business cycle varies from 73 to 91 months (EC, 2003; NBER, 2010).

In order to determine the status quo and identify the impact of restructuring on the business perspective of the SME, the conservative forecast was used throughout the paragraphs of this paper with the following key assumptions: a) the annual average rate of increase by $3 \%$ for expenditures categories basing upon the statistics of index of manufacturing producer prices since 2010 (Eurostat, 2013); b) the annual average rate of increase by $2 \%$ for categories of revenues basing upon statistics of the harmonised index of consumer prices (lower figures of the EU were deliberately chosen) since 2010 (Eurostat, 2013).

\section{Rationalizing Management of SME}

The rationalization of management functions of SME is determined by specifics of its activity, i.e. the strategy, the nature of product, its market and human, material and financial resources. In order to rationalize SME management for modelling corporate management decisions 


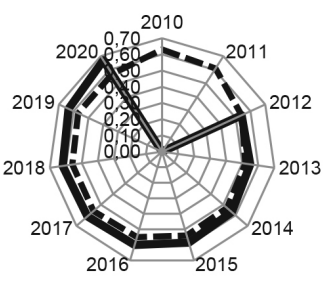

Assets turnover rate without restructuring

Assets turnover rate after restructuring

a) Asset turnover dynamics

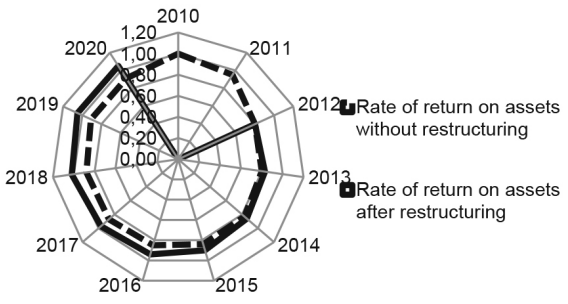

c) Return on assets dynamics

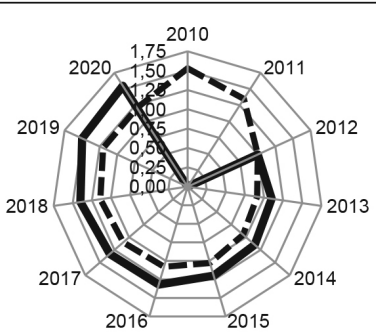

LCurrent liquidity ratio without restructuring

Current liquidity ratio after restructuring

b) Current liquidity dynamics

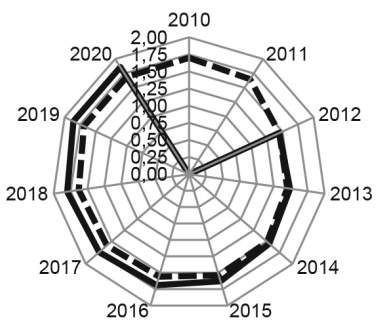

Labor productivity without restructuring

- Labor productivity after restructuring

d) Labour productivity (i.e. strategic, administrative, functional and operational) and their possible combinations, it is necessary to evaluate the characteristics of SME products, markets per its activity as well as enterprise strategy, functional strategies and their interdependence.

For instance, dependence of enterprise strategy efficiency on functional management decisions could be as follows:

$$
E_{s}=f\left(E_{s 1}, E_{s 2}, \ldots, E_{s n}\right)
$$

where $E_{s}$ - the efficiency of enterprise strategy, $E_{s i}=f\left(E_{i 1}, E_{i 2}, \ldots, E_{i n}\right)$ - the efficiency of functional strategies (i.e. finance, production, marketing, management of human resources and information flows), $E_{s j}=f\left(E_{j 1}, E_{j 2}, \ldots, E_{j n}\right)-$ the efficiency $E_{s j}$ of function $j$ as to implement efficiently the functional strategy (to achieve the respective level of efficiency $E_{s i}$ of the functional strategy), $E_{j 1}, E_{j 2}, \ldots, E_{j n}$ - efficiency of operations as to efficiently implement the function $j$ (to achieve respective level of the efficiency $E_{s j}(j=1, \ldots, n)$ of the function).
In this context, the efficiency of operation to be executed to efficiently implement the function $j$ (to achieve respective level of the efficiency $E_{j}$ of the function) could be characterized as follows:

$$
E_{j k}=f\left(w_{k 1}, w_{k 2}, w_{k 3}, w_{k 4}, w_{k 5}, w_{k 6}, w_{k 7}, w_{k 8}, w_{k 9}\right),
$$

where the factors determining the efficiency of operation $k$ to be executed to implement function $j$ are as follow: $w_{k 1}$ - number of employees, necessary to execute the operation; $w_{k 3}$-input of time, necessary to execute the operation; $w_{k 8}=\sum_{j}\left(y_{k j} / y_{n j}\right)$ - homogeneity with respect to other operations of function $j\left(y_{k j}-\right.$ characteristic of operation $k$ of function $j\left(k=w_{k 1}, \ldots, w_{k 7}\right) ; y_{n j}$ - characteristics of operations $n$ of function $j ; n=1, \ldots, l) ; w_{k 9}-$ actual carbon emission amount emitted when executing operation $k$ to implement function $j$ will be measured (by respective physical measurement devices as to respective legitimate standards and norms) by environmental protection or production either 
other respective organisational unit assigned on a daily basis in quantitative terms.

The following indicators show the level of qualification of employees $w_{k 2}$ necessary to execute operation $k$ for function $j$; the level of specialization $w_{k 4}$; value of vertical/horizontal links with respect to other operations $w_{k 5}$; the need of information $w_{k 6}$; the standardization level of operation execution $w_{k 7}$ are proposed to be evaluated by scores (applying a ten-point evaluation system).

In order to ensure the comparability of quantitative $\left(w_{k 1}, w_{k 3}, w_{k 8}, w_{k 9}\right)$ and qualitative $\left(w_{k 2}, w_{k 4}, w_{k 5}, w_{k 6}, w_{k 7}\right)$ indicators, it is proposed for qualitative indicators to attribute the value of scores (applying the ten-point evaluation system) having evaluated the significance of quantitative indicator on the basis of comparison of its quantitative value of the period considered with the average of its quantitative values per last three years of enterprise activity.

Having determined the values of factors pertaining to the efficiency $E_{j}$ of operation $k$ of function $j$, the importance coefficients of these characteristics can be calculated in the following manner:

$$
Y_{e}=N_{e} / \sum_{e} N_{e}
$$

where $Y_{e}-$ importance of value of indicator $e$; $N_{e}$ - value in scores of indicator $e$.

In the case of the SME-construction materials producer, having characterized its strategic management functions (Fig. 6) and compared them, it was found that it is expedient to improve its pivotal management functions in the following manner:

a) managing human resources - must implement the measures increasing potential of human resources with respect to product $g_{1}$ and strengthen the links with other strategic management functions of product $g_{1}$; due to the homogeneity of operations of human resource management functions between products $g_{1}$ and $g_{2}$, it is expedient to use the human resource management techniques applied in the context of product $g_{1}$ for management of personnel working with product $g_{2}$;

b) as for strategic management, it should be ensured (in the context of product $g_{1}$ ) that operations are executed flexibly, operatively, and information is provided on time; strategic management operations of product $g_{1}$ may be partially standardized and applied for product $g_{2}$ management;

c) managing financial instruments - to ensure timely provision of information and reach the maximal standardization of operations with respect to product $g_{1}$;

d) managing production - to apply product $g_{1}$ production organisation techniques for product $g_{2}$ production on a broader scale and ensure timely provision of information;

e) managing marketing instruments - to increase standardization of operations pertaining to marketing functions of product $g_{1}$ and partially apply them in the process of development (production) and sale of product $g_{2}$; due to the importance of time input with respect to product $g_{1}$, it is expedient to ensure that this function is executed flexibly and operatively;

f) as for carbon emission volumes, it is expedient to consider efficiency measures with regard to delivery networks efficiency and production of product $g_{2}$.

Having identified values of enterprise business process management characteristics in terms of enterprise strategy efficiency, it is necessary to evaluate the effect of enterprise product characteristics to the efficiency of enterprise strategy (Tamošiūnas, 2014).

The efficiency of enterprise product could be characterized by these criteria:

$$
\begin{aligned}
& E_{g b}=f\left(z_{g 1}, z_{g 2}, z_{g 3}, z_{g 4}, z_{g 5}, z_{g 6}, \ldots\right. \\
& \left.\ldots z_{g 7}, z_{g 8}, z_{g 9}, z_{g 10}, z_{g 11}, z_{g 12}\right),
\end{aligned}
$$

where the characteristics outlining $E_{g b}$ efficiency of product $g(g=1, \ldots, n)$ in market $b(b=1 \ldots l)$ are the following: competitiveness $z_{g 4}\left(E_{1}\right)$; profitability $z_{g 5}$; market share $z_{g 6}\left(E_{3}\right.$; the latter indices are formalized in para. 7 ); number of segments $z_{g 7} ; z_{g 8}=\sum\left(y_{g p} / y_{n p}\right)$ - homogeneity $\left(y_{g p}\right.$ - characteristic $\dot{p}$ of product $g(g=1, \ldots, l)$; $y_{n p}$ - characteristic $p$ of product $\left.n ; n=1, \ldots, l\right)$; financial $\left(z_{g 9}=T_{1 g} / T_{1} ; T_{1 g}\right.$ - the share of working capital used for product $g$ development (production) and sale; $T_{1}$ - working capital), human $\left(z_{g 10}=C^{g}{ }_{z 10} / C^{g} ; C^{g}{ }_{z 10}-\right.$ costs of human resources used for product $g$ development (production) and sale, $C^{g}$ - costs of product $g$ development (production) and sale), material $\left(z_{g 11}=T_{2 g} / T_{2} ; T_{2 g}\right.$ - share of long-term assets used for product $g$ development (production) and sale, $T_{2}$ - long-term assets) resources of enterprise, used for product $g$ development (production) and sale. 

products $\mathrm{g}_{1}$ and $\mathrm{g}_{2}$

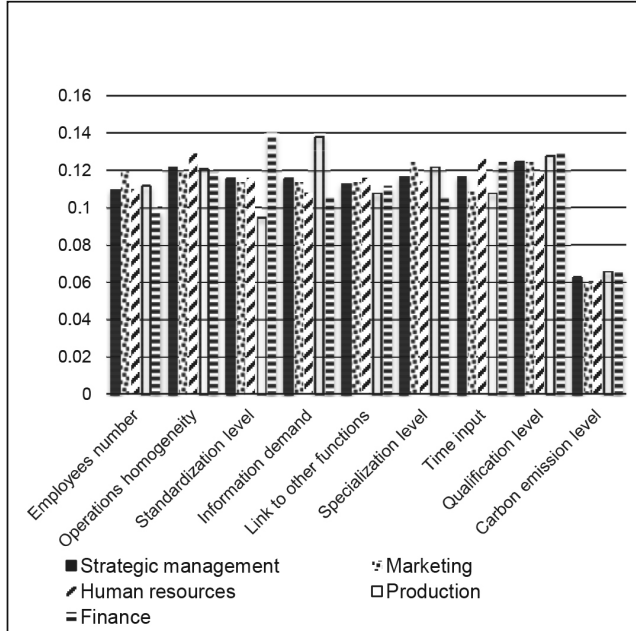

a) $g_{1}$ management functions

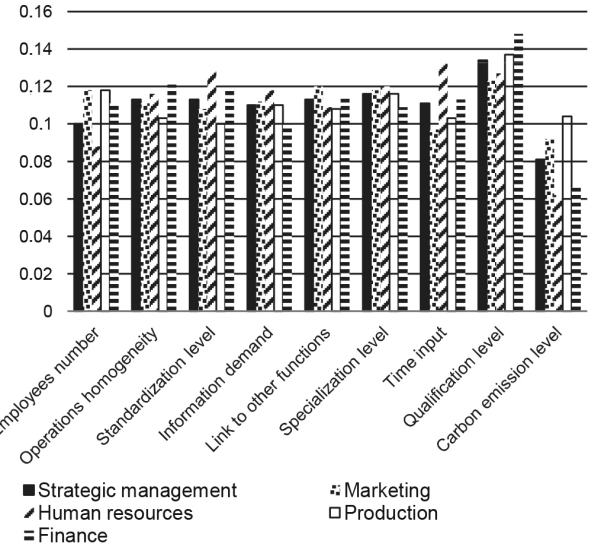

b) $g_{2}$ management functions
The number of competitors $z_{g 3}$ and segments $z_{g 7}$ can be easily identified having investigated the markets subject to the sale of enterprise products in quantitative terms.

The seasonal index $z_{g 2}$ can be calculated according to the equation:

$$
Z_{g 2}=R_{t}^{g} / \mu_{t},
$$

where $R^{g}{ }_{t}$ - sales of product $g$ for considered period $(t=1, \ldots, n) ; \mu_{t}$ - the average of values of product $g$ sales under considered time-series for the respective period $t$.

It is expedient to evaluate the indicators (formula 8) as evolution cycle phase (its significance) $z_{g 1}$, the ratio of vertical and horizontal integration $z_{g 12}$ for the development (production) and sale of products using the expertise technique (applying the ten-point evaluation system). The importance of values of product characteristics can be determined applying formula 7 .

Having characterized the products of the SME-construction materials producer and determined the importance of values of their characteristics as well as their dependence on markets, where these products are sold (Fig. 7) as well as having taken into account the above made conclusions on the impact of functional strategies of enterprise business management on the efficiency of analysed SME strategy the following conclusions were made:

a) in order to rationalize management of product $g_{1}$ in market $b_{1}$ it is expedient to apply innovative or adaptive management principles;

b) in order to rationalize management of $g_{1}$ product in $b_{3}$ market, the principle of decentralized management can be applied;

c) it is expedient for products $g_{1}$ and $g_{2}$ in market $b_{2}$ to unify or, with respect to business development, apply principles of adaptive or innovative management.

Applying the techniques described in this paragraph, the dominating characteristics of enterprise management functions and their operations can be identified. On the basis of these characteristics, SME strategic 


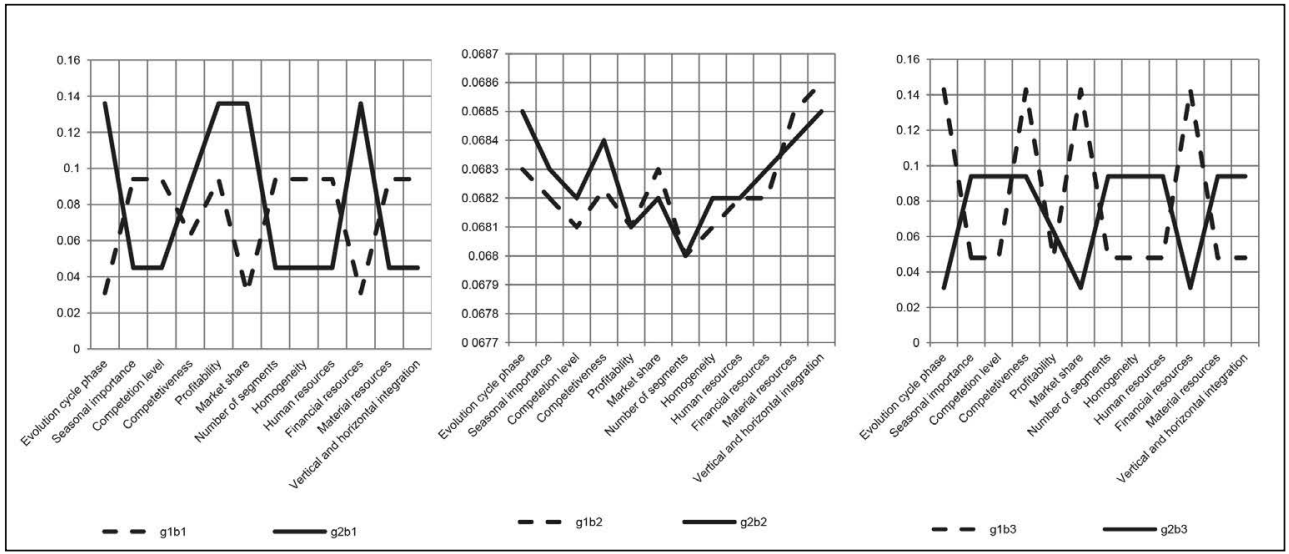

Source: own

management functions could be rationalized at the level of enterprise and its functional departments or business units.

\section{Assessing the Restructuring Benefit}

No specific method for assessing the effectiveness of restructuring was found in literature. It was observed that usually ordinary methods for analysis and evaluation of effectiveness of an enterprise activity are chosen, although the concept of competitiveness is used often. In this respect, literature presents a vast system of indicators. Having summarised possible indicators for evaluation of the effectiveness of restructuring, the respective model (Tamošiūnas, 2014) was proposed, which generalised the expression (Eq. 10) as follows:

$$
\begin{aligned}
& E_{R}=f\left(E_{1}, E_{2}, E_{3}, E_{4}, E_{5}\right) \geq E^{0}= \\
& =f\left(E_{1}^{0}, E_{2}^{0}, E_{3}^{0}, E_{4}^{0}, E_{5}^{0}\right),
\end{aligned}
$$

where $E_{R}$ - the benefit of restructuring (e.g., the respective programme and/or the action plan); $E_{1}$ - product competitiveness; $E_{2}$ - enterprise productivity; $E_{3}$ - market share; $E_{4}$ - business development potential; $E_{5}$ - financial capacity; $E_{1}^{0}, E_{2}^{0}, E_{3}^{0}, E_{4}^{0}, E^{0}{ }_{5}$ - indicators of product competitiveness, enterprise productivity, market share, business development potential, financial capacity of enterprise activity when restructuring programme (or respective action plan) is not implemented; $E^{0}$ - enterprise activity effectiveness when restructuring programme is not implemented.

In the context of the model stated above, the calculated indicators for the enterprise with implemented restructuring programme are compared with the respective ones determined for the enterprise when restructuring programme is not implemented.

It is proposed to use the following principles when evaluating effectiveness of restructuring programmes under the above described model:

- the results of restructuring can be considered satisfactory when there is only one indicator less and there is also at least one higher than the respective ones of the enterprise when the restructuring programme is not implemented;

- the results of restructuring can also be considered satisfactory when there are at least three indicators, values of which are higher than the ones of the enterprise when the restructuring programme is not implemented.

Other modifications are proposed to be defined as subject to non-satisfactory results of restructuring.

The proposed principles of assessment of restructuring results present a possibility to determine the minimal necessary level of the benefit of implemented restructuring measures and evaluate the effectiveness of each management area of any SME in question (Tamošiūnas, 2014). 


\section{Conclusions}

The proposed integrative management model for SME restructuring programmes gives the following possibilities:

- to justify the need for restructuring, identifying and evaluating possibilities to increase efficiency of SME activity and its development as well as the perspective of its strategy within the context of divergent and sustained competitive advantages;

- to prepare the programme for SME restructuring determining restructuring strategy and ways for the increase of efficiency of enterprise activity, rationalizing the use of human, material and financial resources and creating possibilities to attract external resources;

- to rationalize the strategic management of an enterprise, ensuring the effective use of resources and control of main processes of the activity as well as its flexibility;

- to improve the management of an enterprise, increasing the management effectiveness of independent business units and functional departments;

- to evaluate benefit of the restructuring programme and identify directions and actions needed to continue improving the efficiency of enterprise activity.

The results of the paper could contribute to the inputs of further research on SME restructuring, for instance, investigating covariance of factors of size and maturity of SME, its restructuring objectives and techniques.

\section{References}

Aidis, R., \& Van Praag, M. (2007). Illegal entrepreneurship experience: does it make a difference for business performance and motivation? Journal of Business Venturing, 22(2), 283-310. doi:10.1016/j.jbusvent.2006.02.002.

Anderson, C. (2008). The Long Tail: Why the Future of Business is Selling Less of More. New York, NY: Hyperion.

Bosma, N., \& Amoros, J. E. (2013). GEM Global Entrepreneurship Monitor, 2013 Global Report. Global Entrepreneurship Research Association (GERA).

Bulgarian Small and Medium Enterprises Promotion Agency (BSMEPA). (2011). Analysis of the situation and factors for development of SMEs in Bulgaria, SMEs in the crisis context. Sofia: Noema, Sofia.
Cope, J. (2011). Entrepreneurial learning from failure: An interpretative phenomenological analysis. Journal of Business Venturing, 26(6), 604-623. doi:10.1016/j.jbusvent.2010.06.002.

CSO. (2008). International sourcing: Moving Irish business activity abroad. Dublin.

De Kok, J., Vroonhof, P., Verhoeven, W., Timmermans, N., Kwaak, T., Snijders, J., \& Westhof, F. (2011). Do SMEs create more and better jobs? Zoetermeer: EIM.

Dervillé, M., \& Allaire, G. (2014). Change of competition regime and regional innovative capacities: Evidence from dairy restructuring in France. Food Policy, 49, 347-360. doi:10.1016/j.foodpol.2014.09.002.

Deschryvere, M., \& Kotiranta, A. (2008). Domestic employment effects of offshoring: Empirical evidence from Finland [Discussion Papers No. 1166]. The Research Institute of the Finnish Economy.

EC. (2003). Statistical Methods for Potential Output Estimation and Cycle Extraction. EC, Brussels.

EC. (2005). The New SME Definition: User Guide and Model Declaration. DG Enterprise and Industry Publications.

EC. (2006). Communication from the Commission to the Council, the European Parliament, the European Economic and Social Committee and the Committee of the Regions, Implementing the Lisbon community programme for growth and jobs, transfer of businesses - continuity through a new beginning, $\mathrm{COM(2006)} 117$ final, Brussels: EC.

EC. (2013a). A recovery on the horizon? Brussels: EC.

EC. (2013b). Conclusions on multiannual financial framework, No EUCO 37/13.

EC. (2007). Supporting the internationalization of SMEs. Brussels: DG Enterprise and Industry.

EIM, Ikei Research and Consultancy. (2009). EU SMEs and subcontracting, Zoetermeer/Brussels.

EIM. (2010). Internationalisation of European SMEs. Zoetermeer/Brussels: European Commission, Directorate-General for Enterprise and Industry.

Eurostat. (2011). The proportion of unsuccessful loan applications by SMEs has risen with the economic crisis [Eurostat news release 144/2011].

Eurostat. (2013). Eurostat yearbook 2012. Eurostat. 
Galbraith, C., Rodriguez, C., \& DeNoble, A. (2008). SME Competitive strategy and location behavior: an exploratory study of high-technology manufacturing. Journal of Small Business Management, 46(2), 183-202. doi:10.1111/j.1540-627X.2008.00239.

Gallup. (2007). Observatory of European SMEs. Analytical report [Flash Eurobarometer 196]. Brussels: European Commission.

Gladwell, M. (2000). The tipping point: how little things can make a big difference. Little Brown.

Grüne, H. P. (2009). Information technology: Efficient restructuring and the productivity puzzle. Journal of Economic Behavior \& Organization, 72(3), 916-929. doi:10.1016/j.jebo.2009.09.003.

IME GSEVEE. (2012). Economic climate trends, Athens: GSEVEE small enterprises institute.

Kelly, D. J., Bosma, N., \& Amoros, J. E. (2011). GEM Global Entrepreneurship Monitor, 2010 Global Report. Global Entrepreneurship Research Association (GERA).

Kontinen, T. (2011). Internationalization pathways of family SMEs (Doctoral dissertation). Retrieved from Jyvaskyla Studies in Business and Economics (100).

Kitching, J., Hart, M., \& Wilson, N. (2010). Regulation: constraint on, or enabler of, business performance? Evidence from UK small enterprises. Maastricht: RENT XXIV: Research in Entrepreneurship and Small Business, November 17-20.

Kitching, J., Smallbone, D., Xheneti, M., \& Kasperova, E. (2011). Adapting to a fragile recovery: SME responses to recession and post-recession performance. Institute for Small Business and Entrepreneurship (ISBE). Sheffield: 34th Annual Conference, 'Sustainable futures: enterprising landscapes and communities' 9-10 November 2011.

Kowalewska, A. (2010). Firmy rodzinne w polskiej gospodarce - szanse $i$ wyzwania. Warsaw: Polska Agencja Rozwoju Przedsiębiorczości.

Kowalska, I. J. (2015). Challenges for long-term industry restructuring in the Upper Silesian Coal Basin: What has Polish coal mining achieved and failed from a twenty-year perspective? Resources Policy, 44, 135-149. doi:10.1016/j.resourpol.2015.02.009.

KPMG. (2007). Thinking Big! SME Action Day. Brussels: Business Europe.
KPMG. (2009). Redukcja kosztow doraźna potrzeba czy długofalowe działanie? KPMG.

Mandl, I. (2008). Overview of family business relevant issues. Final Report. Brussels: European Commission.

NBER Business Cycle Dating Committee. (2010, September 20). Report of National Bureau of Economic Research (NBER), US. Retrieved from: http://www.nber.org/cycles/ sept2010.pdf.

OECD. (2013). Entrepreneurship at a Glance 2013. Paris: OECD.

Orłowski, W., Pasternak, R., Flaht, K., \& Szubert, D. (2010). Procesy inwestycyjne $i$ strategie przedsiębiorstw w czasach kryzysu. Warszawa: Polska Agencja Rozwoju Przedsiębiorczości.

Ruiz, J., \& Coduras, A. (2015). Can company restructuring create a healthier work environment, promote corporate entrepreneurship, and improve productivity? Journal of Business Research, 68(7), 14661467. doi:10.1016/j.jbusres.2015.01.035.

Sauka, A., \& Welter, F. (2014). Determinants of Business Insolvencies During Economic Growth and Recession in Latvia. Journal of Baltic Studies, 45(3), 375-396. doi:10.1080/01629778.2013.848372.

Tamošiūnas, A. (2014). The model for evaluation of corporate strategic changes in the context of climate change: plywood manufacture. Journal of Business Economics and Management, 15(1), 135-152. doi:10.3846/ 16111699.2013.801880.

Voss, E. (2009). Cooperation between SMEs and trade unions in Europe on common economic and social concerns. Hamburg: Wilke, Maack und Partner.

Wymenga, P., Spanikova, V., Barker, A., Konings, J., \& Canton, E. (2012). EU SMEs in 2012: at the crossroads. Rotterdam: EC, Ecorys.

4Results. (2009). Raport poświęcony zmianom strategii zarządzania w polskich przedsiębiorstwach w okresie kryzysu gospodarczego w 2009 roku. Warsaw: 4Results.

Assoc. Prof. Andrius Tamošiūnas, Ph. D. Vilnius Gediminas Technical University Faculty of Business Management Department of Social Economics and Management andrius.tamosiunas@vgtu.It 


\section{Abstract}

\section{THE INTEGRATIVE MANAGEMENT MODEL FOR RESTRUCTURING SMALL AND MEDIUM-SIZED ENTERPRISES (SME)}

\section{Andrius Tamošiūnas}

The article presents the integrative SME restructuring management model. The model is aimed at divergent and sustained competitive performance, specifying measures for improving strategic management, rationalizing management functions and assessing influence of its results on SME competitiveness. The respective technique is proposed for enterprise efficiency evaluation in terms of strategic and functional management. As to prepare the proper strategy for SME restructuring the author have determined and hence recommend the regularities for strategic decisions making towards restructuring as well as the ones for the rational selection of restructuring techniques. When executing SME restructuring author proposes to use the complex set of measures determined in order to ensure the reasonable efficiency of functions of the enterprise as well as its products. In order to ensure rational management of restructuring the respective technique is also proposed to evaluate the efficiency of SME restructuring. This let as to evaluate the benefit of the executed changes within the enterprise as to identify the directions and actions needed to continue increasing the efficiency of the enterprise activity.

Based on the outcome of empirical investigations of SME restructuring in the EU over the last decade, underlining its specifics and complexity, the paper reveals the benefit of use of the proposed model specifying all its phases to relevant techniques and actions.

Results of its application in practice also confirm the prevailing flexibility when applying the model while characteristics of the complex of measures set under the latter can be adjusted to the specifics of SME and its business environment. While leading to greater possibilities to rationalize restructuring process, the model created by the author also provides an SME with prerequisites to improve the use and development of human, material and financial potentials with pivotal contribution to its sustained competitiveness even in a changing business environment.

Key Words: SME, restructuring, management, competitiveness, performance, business development.

JEL Classification: M11, M13, M21, M29.

DOI: 10.15240/tul/001/2017-3-003 